\title{
Opportunities for blue carbon strategies in China
}

\section{Jiaping $\mathrm{Wu}^{\mathrm{a} \text {,* }, \text { Haibo Zhang }}{ }^{\mathrm{b}, \mathrm{c}}$, Yiwen Pan ${ }^{\mathrm{a}}$, Dorte Krause-Jensen ${ }^{\mathrm{d}, \mathrm{e}}$, Zhiguo He ${ }^{\mathrm{a}}$, Wei Fan ${ }^{\mathrm{a}}$, Xi Xiao ${ }^{a}$, Ikkyo Chung ${ }^{f}$, Nuria Marbà ${ }^{g}$, Oscar Serrano ${ }^{h, i}$, Richard B. Rivkin ${ }^{j}$, Yuhan Zheng ${ }^{a}$, Jiali Gu ${ }^{a}$, Xiujuan Zhang ${ }^{\mathrm{a}}$, Zhaohui Zhang ${ }^{\mathrm{a}}$, Peng Zhao ${ }^{\mathrm{k}}$, Wanfei Qiu ${ }^{1}$, Guangcheng Chen ${ }^{\mathrm{m}}$, Carlos M. Duarte ${ }^{i, n, * *}$}

${ }^{\text {a }}$ Ocean College, Zhejiang University, Zhoushan, China

${ }^{\mathrm{b}}$ School of Environmental and Resource Sciences, Zhejiang A\&F University, Hangzhou, China

${ }^{\mathrm{c}}$ Yantai Institute of Coastal Zone Research, Chinese Academy of Sciences, Yantai, China

${ }^{\mathrm{d}}$ Department of Bioscience, Aarhus University, Silkeborg, Denmark

${ }^{\mathrm{e}}$ Arctic Research Centre, Aarhus University, Århus, Denmark

${ }^{\mathrm{f}}$ Department of Oceanography, Pusan National University, Busan, Republic of Korea

${ }^{g}$ Department of Global Change Research, IMEDEA (CSIC-UIB), Institut Mediterrani d'Estudis Avançats, Esporles, Illes Balears, Spain

${ }^{\mathrm{h}}$ School of Science, Centre for Marine Ecosystems Research, Edith Cowan University, Perth, WA, Australia

${ }^{i}$ Oceans Institute, The University of Western Australia, Perth, WA, Australia

${ }^{\mathrm{j}}$ Department of Ocean Sciences, Memorial University of Newfoundland, St. John's, NF, Canada

${ }^{\mathrm{k}}$ National Marine Information Center, Ministry of Natural Resources, Tianjin, China

${ }^{1}$ China Institute for Marine Affairs, Ministry of Natural Resources, Beijing, China

${ }^{\mathrm{m}}$ Laboratory of Marine Biology and Ecology, Third Institute of Oceanography, Ministry of Natural Resources, Xiamen, Fujian, China

${ }^{\mathrm{n}}$ Red Sea Research Center, King Abdullah University of Science and Technology, Thuwal, Saudi Arabia

\section{A R T I C L E I N F O}

\section{Keywords:}

Blue carbon

China

Co-benefits

Strategies

Opportunities

Seagrass

Saltmarsh

Mangrove

Seaweed aquaculture

$\mathrm{CO}_{2}$ sequestration

\begin{abstract}
A B S T R A C T
Blue Carbon (BC) strategy refers to the approaches that mitigate and adapt to climate change through the conservation and restoration of seagrass, saltmarsh and mangrove ecosystems and, in some BC programs, also through the expansion of seaweed aquaculture. The major losses of coastal habitats in combination with the commitments of China under the Paris Agreement provide unique opportunity and necessity to develop a strong Chinese BC program. Here, we (1) characterize China's BC habitats, examine their changes since 1950 along with the drivers of changes; (2) consider the expansion of seaweed aquaculture and how this may be managed to become an emerging BC resource in China, along with the engineering solutions required to enhance its potential; and (3) provide the rationale and elements for BC program in China. We find China currently has $1326-2149 \mathrm{~km}^{2}$ wild and $2-15 \mathrm{~km}^{2}$ created mangrove, saltmarsh and seagrass habitats, while $9236-10059 \mathrm{~km}^{2}$ (77-87\%) has been lost since 1950, mainly due to land reclamation. The current area of farmed seaweed habitat is $1252-1265 \mathrm{~km}^{2}$, which is close to the area of wild mangrove, saltmarsh and seagrass habitats. We conclude that BC strategies have potentials yet to be fully developed in China, particularly through climate change adaptation benefits such as coastal protection and eco-environmental co-benefits of seaweed farming such as habitat creation for fish and other biota, alleviation of eutrophication, hypoxia and acidification, and the generation of direct and value added products with lower environmental impact relative to land-based production. On this basis, we provide a roadmap for BC strategies adjusted to the unique characteristics and capacities of China.
\end{abstract}

\section{Introduction}

China, which currently represents $22 \%$ of the world population and accounts for $12 \%$ of global emissions of green-house gases and black carbon (Kong et al., 2016), has adopted the Paris Agreement, pledging to reduce the rate of growth in carbon emissions and to reach the peak of

\footnotetext{
* Corresponding author. 1 Zheda Road, Zhoushan, Zhejiang, 316021, China.

** Corresponding author. Red Sea Research Center, King Abdullah University of Science and Technology, Thuwal, Saudi Arabia.

E-mail addresses: jw67@zju.edu.cn (J. Wu), carlos.duarte@kaust.edu.sa (C.M. Duarte).
} 
$\mathrm{CO}_{2}$ emissions by 2030. Because of its large share of global emissions, the commitment by China is a key to the success of the Paris Agreement. However, achieving the goal of reduced emissions while pursuing its socio-economic development poses a great challenge to China, which requires using the broadest possible range of options to reduce and avoid emissions, while also adapting to climate change. Indeed, China is particularly vulnerable to sea level rise with a large proportion of its population at risk in coastal megacities which have already experienced severe losses due to typhoons and floods (Guan et al., 2015; Nicholls et al., 2007). For instance, super typhoon"Meranti"that made landfall in Xiamen, Fujian province on September 15, 2016, causing direct economic losses of 10.2 billion RMB, severe damage to natural ecological system of the whole city, killing 48 and injuring another 49 persons. From 2012 to 2017, the direct economic losses caused by storm surges in China have exceeded 9.8 billion RMB annually, which accounts for more than $91 \%$ of the total direct economic losses by all marine disasters. As China is still a developing nation, with a large population in need additional energy production for further development, some of the options being considered by wealthy and more developed nations cannot form the underpinnings of the Chinese strategy to fulfill their commitment to mitigate climate change. When considering the range of options to be included in national policies, preferred mitigation options should include those that are readily actionable, cost-effective and generate co-benefits, in terms of climate-change adaptation and added value towards other national priorities, while delivering the national commitments under the Paris Agreement.

Blue Carbon (BC) strategies, referring to approaches to mitigate and adapt to climate change based on conservation and restoration of vegetated coastal habitats such as seagrasses, saltmarshes, and mangroves (Duarte et al., 2013; Mcleod et al., 2011; Nellemann et al., 2009), have been recently adopted by many coastal nations as cost-effective strategies that are particularly suitable for developing nations with extensive coastlines (van Kleef et al., 2016). In addition, mangroves, saltmarshes, and seagrass meadows can significantly attenuate wave energy and raise the seafloor, thus protecting the shoreline from sea level rise and erosion (Duarte et al., 2013; Kirwan and Megonigal, 2013). Coastal areas with marine vegetation form important natural buffers against typhoon and wave destruction, flooding erosion of farmland and wetland. Kelp forests have similar capabilities, for example, Norwegian kelp forests have been found to reduce wave heights by up to 60\% (Mork, 1996). Farmed seaweeds, prominent in China, could play similar roles, helping protect coastal land from flooding and erosion while contributing to avoid greenhouse gas emissions (Duarte et al., 2017).

Vegetated coastal ecosystems (mainly mangroves, saltmarshes and seagrasses) are particularly effective at capturing $\mathrm{CO}_{2}$ from the atmosphere and storing them in the roots and soils/sediments as blue carbon sinks, which could contribute to global greenhouse gas emission mitigation (e.g. Duarte et al., 2013; Gattuso et al., 2018). These blue carbon habitats have experienced major losses globally, thereby offering opportunities to restore these lost habitats. $\mathrm{BC}$ strategies involve a suite of actions to conserve and restore BC habitats to contribute to climate mitigation (Duarte et al., 2013). BC habitats are efficient at long-term sequestration of organic carbon by burying a fraction of their own production in the soils/seabeds (Krause-Jensen and Duarte, 2016). By altering turbulence, flow and wave action, these habitats promote sedimentation and accumulate significant quantities of allochthonous carbon and nutrients (Kennedy et al., 2010). While BC strategies are rooted in angiosperm-dominated coastal habitats, there is increasing recognition of the role that seaweeds, both wild and cultivated, can play in climate change mitigation and adaptation (Duarte et al., 2017; Froehlich et al., 2019; Krause-Jensen and Duarte, 2016; Krause-Jensen et al., 2018; Lovelock and Duarte, 2019) and the need to increase our understanding on the role of seaweed in carbon sequestration and the fate of their carbon (Macreadie et al., 2019). Seaweeds release both particulate and dissolved organic carbon (Hill et al., 2015;
Krause-Jensen and Duarte, 2016), which can be buried into sediments or transported into deep sea, thus acting as a $\mathrm{CO}_{2} \operatorname{sink}$ (Duarte et al., 2017; Ortega et al., 2019; Queirós et al., 2019). In contrast to angiosperm-dominated coastal habitats, which are declining globally (Duarte et al., 2013), wild seaweed communities seem to be globally stable, with declines in some areas being compensated by expansions elsewhere (Krumhansl et al., 2016). Meanwhile, the global growth of seaweed aquaculture, now covering $1600 \mathrm{~km}^{2}$ globally (Duarte et al., 2017), provides food and raw materials to large segments of the human populations, and offers an emerging opportunity to contribute to BC-based strategies (Duarte et al., 2017; Krause-Jensen et al., 2018; Lovelock and Duarte, 2019) because of its scalability in contrast to the limited scope for angiosperm-dominated BC strategies (Gattuso et al., 2018).

China has an extensive coastline, spanning 18,000 km along its continental area and $32,000 \mathrm{~km}$ when including its islands. The coastline has experienced abrupt transformation, including massive coastal habitat loss involving about $51 \%$ of coastal wetlands and $69 \%$ of mangrove forests loss due to reclamation, mostly over the past 20 years (Zhang et al., 2005). On the other hand, China accounts for about $70 \%$ of global seaweed aquaculture (FAO, 2010). Hence, China meets the criteria to adopt BC strategies within the range of policies best suited to respond to climate change. China is now preparing to join the growing pool of nations that have adopted and developed national BC programs. Indeed China has already included BC actions among its Nationally Determined Contributions (NDCs) (Gallo et al., 2017; Herr and Landis, 2016), which represent the basic building blocks of national strategies for implementing the Paris Agreement and reflect the highest possible ambition of the nations to mitigate climate change (Gallo et al., 2017). A recent assessment reported that 27 nations, including China, have included Blue Carbon mitigation contributions in their NDCs, encompassing ocean carbon storage and the protection, replantation, or management of mangroves, saltmarshes, and seagrass (Gallo et al., 2017). For example, "Mangrove in South and Tamarix chinensis in North" project which was started in 2016 by the State Oceanic Administration is mainly focused on the planting mangrove trees in south China and planting saltmarshes vegetation, such as Tamarix chinensis, Phragmites australis, and Suaeda salsa in north China (Ministry of Natural Resources, 2016). However, there is ample scope to broaden the slate of Blue Carbon actions included in NDC's (Gallo et al., 2017). In this context, wild and farmed seaweed are not yet included in NDC's, as further research to document their contribution to carbon sequestration is required before emissions reduction factors can be used in supporting the potential NDCs involving seaweed management (Krause-Jensen et al., 2018; Froehlich et al., 2019; Lovelock and Duarte, 2019).

Here we identify opportunities for BC approaches, including vegetated coastal habitats as recognized $\mathrm{BC}$ habitats and also the emerging role of seaweed aquaculture as potential BC habitats, to help China mitigate and adapt to climate change, thereby developing a roadmap that makes use of the unique characteristics and capacities of China. We first characterize the wild and created BC habitats in China, and examine the changes occurring since 1950, and the drivers for these changes. We then consider the specific case for the expansion of seaweed aquaculture as a unique emerging BC resource in China (Duarte et al., 2017), and the requirement for engineering solutions to enhance its potential. Lastly, we consider the scope for conservation and restoration of BC habitats in the light of its consistency with national policies, and identify the climate-change mitigation and adaptation potential as well as environmental and economic co-benefits of the development of BC strategies in China.

\section{Wild and created blue carbon habitats in China}

Along the $32,000 \mathrm{~km}$ of Chinese coastline, BC habitats (i.e. tidal saltmarsh, mangrove and seagrass ecosystems) together with seaweed farms extend over $3000 \mathrm{~km}^{2}$, about $60 \%$ of which are occupied by wild 
habitats (i.e. habitats that exist without artificial cultivation) and about $40 \%$ are created habitats (i.e. habitats that have been artificially created and maintained). Wild tidal saltmarshes occupy about $1500 \mathrm{~km}^{2}$ (about $82 \%$ of wild BC habitats) (Guan, 2012; Zhang et al., 2005; Zuo et al., 2013), while mangroves and seagrasses account for $13 \%\left(235 \mathrm{~km}^{2}\right)$ and $5 \%\left(88 \mathrm{~km}^{2}\right)$ of wild BC habitat extent, respectively (Zheng et al., 2013). The area of wild seaweeds in China remains unknown (Table 1), while seaweed farms extend across $1250 \mathrm{~km}^{2}$ of China's coast (Xiao et al., 2017) and represent more than $99 \%$ of its created BC habitats and around $41 \%$ of the extension of all (wild and created) current BC habitats (Table 1), with the extent of seaweed farms growing rapidly.

While saltmarshes are distributed all along the entire coast of China, mangroves are restricted to the southeastern China and seagrasses occur in both the North and South (Fig. 1). Eight tidal saltmarsh species have been reported in China (Table 1). Phragmites australis and Suaeda salsa dominate the native tidal saltmarsh vegetation and the invasive species Spartina alterniflora accounts for about $28 \%$ of the total tidal saltmarsh extent (Zhang and Shi, 2007; Zuo et al., 2012). Mangrove forests in China have a high biodiversity with 20 different species present, while five seagrass species have been reported (Table 1).

Organic carbon $\left(\mathrm{C}_{\text {org }}\right)$ stocks in wild mangrove, tidal saltmarsh and seagrass ecosystems in China are estimated to be $12-36 \mathrm{Tg} \mathrm{C}_{\text {org. }}$. Mangrove forests store $39-60 \%$ of Chinese BC while tidal saltmarshes and seagrasses store $28-35 \%$ and $12-25 \%$, respectively. The total $\mathrm{C}_{\text {org }}$ sequestration rates in wild mangrove, tidal saltmarsh and seagrass ecosystems are estimated to be $0.32-0.64 \mathrm{Tg} \mathrm{C}_{\mathrm{org}} \mathrm{yr}^{-1}$. The areal carbon sequestration by mangroves has been estimated at about $4.44 \mathrm{Mg} \mathrm{C} \mathrm{C}_{\text {org }}$ $\mathrm{ha}^{-1} \mathrm{yr}^{-1}$, about $2.36 \mathrm{Mg} \mathrm{C}_{\text {org }} \mathrm{ha}^{-1} \mathrm{yr}^{-1}$ for tidal saltmarsh, and 0.024-0.101 $\mathrm{Mg} \mathrm{C}_{\text {org }} \mathrm{ha}^{-1} \mathrm{yr}^{-1}$ for seagrass ecosystems (Table 1). Carbon storage of mangrove is much more than the carbon stored in saltmarsh and seagrass sediments.

Since 1950, the extent of mangrove forests and tidal saltmarshes in China has declined rapidly. The extent of mangroves between 1950 and 2002 has declined at an overall national rate between $1.2 \% \mathrm{yr}^{-1}$ (Wilkie and Fortuna, 2003) and 5.1\% $\mathrm{yr}^{-1}$ (Fu et al., 2009), averaging 3.5\% $\mathrm{yr}^{-1}$ and, overall, $77-87 \%$ of these habitats have been lost since 1950 (Table 1). The extent of 8 saltmarshes distributed along the entire Chinese coast between 1980 and 2013 decreased at rates varying between $12.2 \% \mathrm{yr}^{-1}$ and $37.8 \% \mathrm{yr}^{-1}$, but when considering the initial size of individual tidal saltmarshes prior to onset of coastal development, they overall declined at an average weighed rate of $3.2 \% \mathrm{yr}^{-1}$ (Table 1). There are no records of temporal changes in the extent of seagrass habitat along Chinese coast. Niu et al. (2012) estimated that $65.4 \%$ of the coastal swamps have been lost between 1978 and 2008, suggesting that extensive areas of seagrass have also been lost. Overall, China experienced a massive development over the last half century, which resulted in the loss and degradation of BC ecosystems at rates of $3.2-3.5 \% \mathrm{yr}^{-1}$ since 1950 (Table 1). Tidal saltmarsh, mangrove and presumably seagrass losses have been related to coastal development activities, including agriculture, aquaculture, and land reclamation for aquaculture ponds, paddy fields, industry and urban construction (Zhang et al., 2005).

Although the areal extent of created BC habitats in China does not compensate for the losses since 1950, it already accounts for $14 \%$ of the estimated losses. This is mainly due to seaweed farming, which has grown at a rate of about $8 \% \mathrm{yr}^{-1}$ since 1950 (Xiao et al., 2017). Since the 1990s, the Chinese government has successfully restored, by planting, $15 \mathrm{~km}^{2}$ of mangrove forests (Chen et al., 2009). There remains a great potential for mangrove expansion along Chinese coasts. Since 2006, the State Forestry Administration and State Oceanic Administration have identified $656 \mathrm{~km}^{2}$ of intertidal zones suitable for mangrove afforestation (Chen et al., 2009). Seagrass planting in small-scale trials was conducted between 1989 and 2008, but it was restricted to artificial reefs (Shu et al., 2011) and aquaculture ponds to improve environmental conditions for shrimp and sea cucumber cultures (Ren et al., 1991). However, seagrass planting failed as majority of seagrass was lost in 1-5 years after planting (van Katwijk et al., 2016). The current capacity of C sequestration by wild BC ecosystems in China is estimated to be $65-80 \%$ lower than before 1950. In this respect, the conversion of mangrove and saltmarshes to aquaculture ponds may have emitted $15-82 \mathrm{Tg} \mathrm{\textrm {CO } _ { 2 }}$ eq $\mathrm{yr}^{-1}$.

Different from the great loss of vegetated coastal habitats, seaweed farming in China increased from 1978 (269,000 tons of dry weight) to present $(1,885,000$ tons of dry weight in 2014) (Xiao et al., 2017). Farmed seaweeds capture into biomass $3.97 \mathrm{Mg} \mathrm{C}_{\mathrm{org}} \mathrm{ha}^{-1} \mathrm{yr}^{-1}$, but the area of wild seaweed in China remains unknown and therefore, it was not possible to estimate their $\mathrm{C}_{\text {org }}$ sequestration capacity at the national scale. Assuming that $24.8 \%$ of the seaweed biomass is $\mathrm{C}_{\text {org }}$ (Duarte, 1992), farming seaweed in China could result in the mitigation of $0.5 \mathrm{Tg}$ $\mathrm{C}_{\text {org }} \mathrm{yr}^{-1}$ (1.82 $\mathrm{Tg} \mathrm{CO}_{2} \mathrm{yr}^{-1}$ ), assuming that all $\mathrm{C}_{\text {org }}$ stored in seaweed biomass be preserved or converted into biofuels, which represents an upper limit that is currently far from being met as much of the biomass is allocated to human consumption. The potential $\mathrm{C}$ mitigation capacity of seaweed (3.97 $\mathrm{Mg} \mathrm{C}_{\text {org }} \mathrm{ha}^{-1} \mathrm{yr}^{-1}$ ) is comparable to the sequestration rate of other $\mathrm{BC}$ ecosystems. The current $\mathrm{CO}_{2}$ removed by farming seaweed is equivalent to $0.01-0.03 \%$ of fossil fuel- $\mathrm{CO}_{2}$ emissions in China (Fig. 2). However, only a small fraction of the $\mathrm{CO}_{2}$ removed by farmed seaweed may be possibly stored at present, although there is ample potential to increase this contribution through the development of biofuels, biochar and soil-amendment industries based on seaweed (Duarte et al., 2017; Froehlich et al., 2019). Moreover, seaweed aquaculture leads to avoided emissions as the $\mathrm{CO}_{2}$ footprint of seaweed aquaculture is much lower than that of producing equivalent amounts of food on land (Duarte et al., 2017; Froehlich et al., 2019; Zheng et al., 2019).

\section{Seaweed aquaculture as a blue carbon resource in China}

Seaweeds are the dominant primary producers in the coastal zone which play an important role in $\mathrm{CO}_{2}$ removal (Duarte and Cebrián, 1996), producing an estimated $1.5 \mathrm{Pg} \mathrm{C}_{\text {year }}{ }^{-1}$ of dry products over the 3.4 million $\mathrm{km}^{2}$ they cover (Krause-Jensen and Duarte, 2016). Despite their major contribution to ocean production, seaweeds have generally not been considered to contribute to marine carbon sinks as they typically grow on rocky substrates that do not accumulate $\mathrm{C}_{\text {org }}$. However, seaweeds release considerable amounts of detritus, both as particulate (Colombini and Chelazzi, 2003; Duarte and Cebrián, 1996; Duggins et al., 2016; Filbee-Dexter and Scheibling, 2012; Krumhansl and Scheibling, 2012), and dissolved organic carbon (DOC) (Barron et al., 2014), comprising about $43.5 \%$ of seaweed production (Duarte and Cebrián, 1996). Seaweed $\mathrm{C}_{\text {org }}$ can subsequently be transported across large distances both as DOC (Barrón and Duarte, 2016), particularly if converted by microbes into recalcitrant DOC forms (Jiao et al., 2010), and particulate $\mathrm{C}_{\text {org }}$ (POC) (Krause-Jensen and Duarte, 2016) to reach ocean carbon sinks (Krause-Jensen and Duarte, 2016; Hill et al., 2015). Despite earlier assumptions that seaweed $\mathrm{C}_{\text {org }}$ was not sequestered into long-term reservoirs (Miller et al., 2009), recent assessments estimate potential seaweed contributions to long-term $\mathrm{C}_{\text {org }}$ sequestration in sediments and the deep sea at $173 \mathrm{Tg} \mathrm{C} \mathrm{yr}^{-1}$ (Krause-Jensen and Duarte, 2016), which render seaweed carbon an emerging component of blue carbon strategies (Krause-Jensen et al., 2018; Lovelock and Duarte, 2019). Moreover, Ortega et al. (2019) reported that $25 \%$ of exported macroalgal carbon is sequestered in long-term reservoirs, such as coastal sediments and the deep sea. Hence, the potential seaweeds contribution to global $\mathrm{C}_{\text {org }}$ sequestration is comparable to that for saltmarshes, seagrass beds and mangroves combined. Therefore, the potential of seaweeds to support $\mathrm{C}_{\text {org }}$ sequestration could provide, when integrated with large-scale seaweed aquaculture appropriately managed to mitigate climate change, an option for climate mitigation (Duarte et al., 2017).

Although $>1200$ species of seaweeds have been described from Chinese coastal waters (Zeng, 1962; Zhang, 1996), their naturally occurring biomass is poorly constrained. The harvest of seaweed and 
Table 1

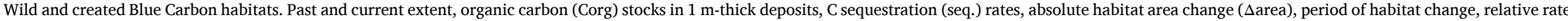

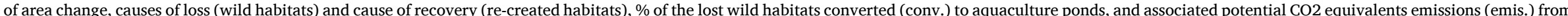

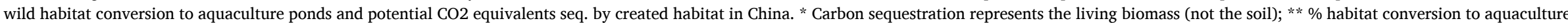
ponds assumed to be the same as for tidal saltmarsh. nd: no data.

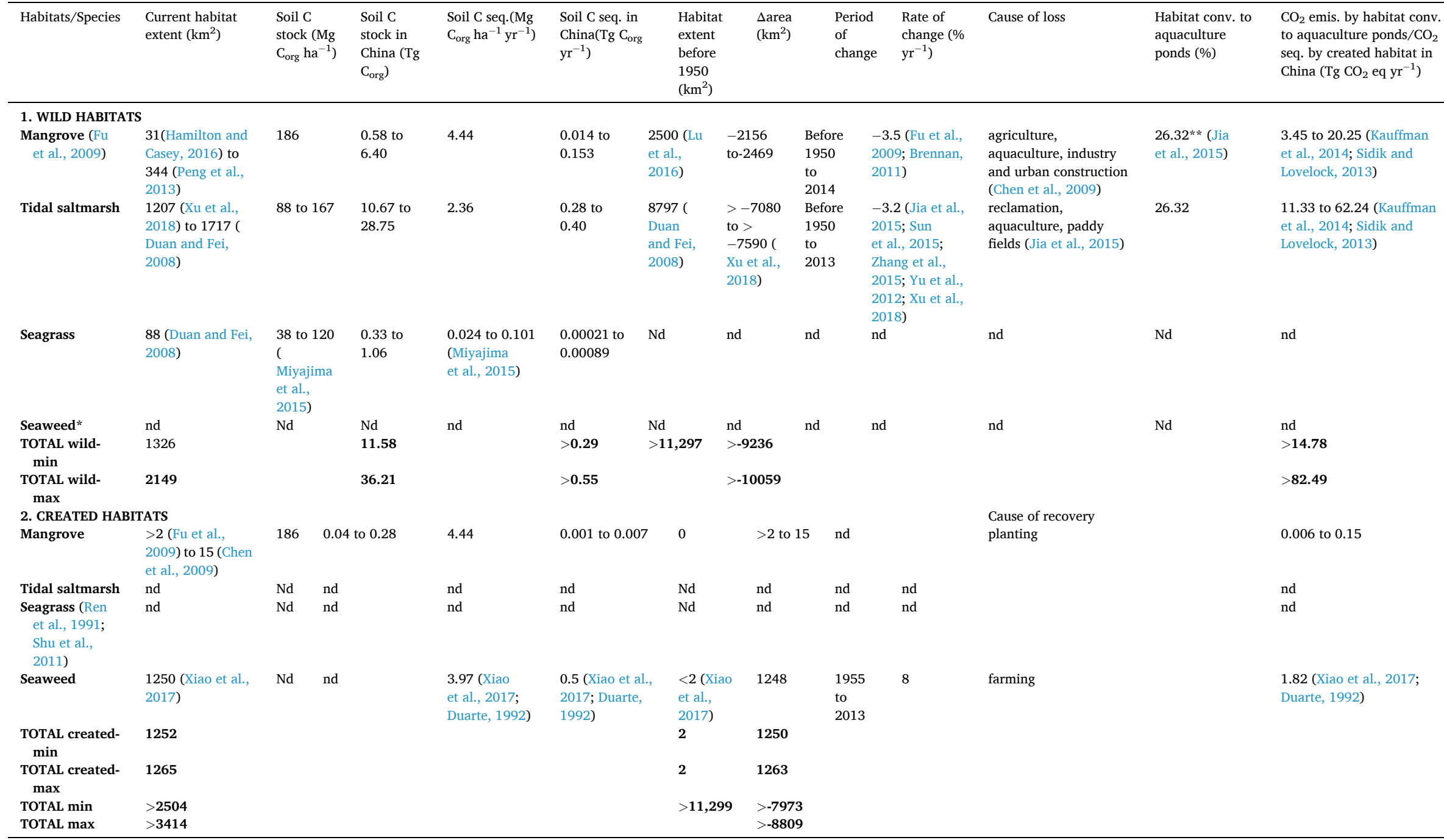

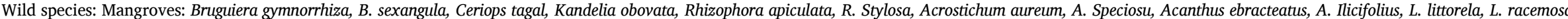

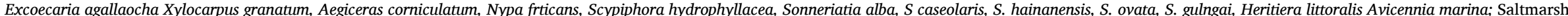

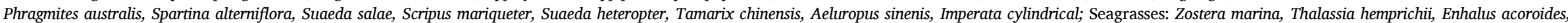
Halophila ovalis, Phyllospadix iwatensis.

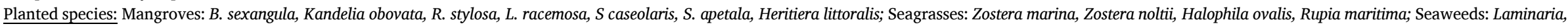
Undaria, Porphyra, Gracilaria, Eucheuma, Sargassum fusiforme, Ulva; aquaculture ponds refer to fish/shrimp/crap/shell fish farming. 


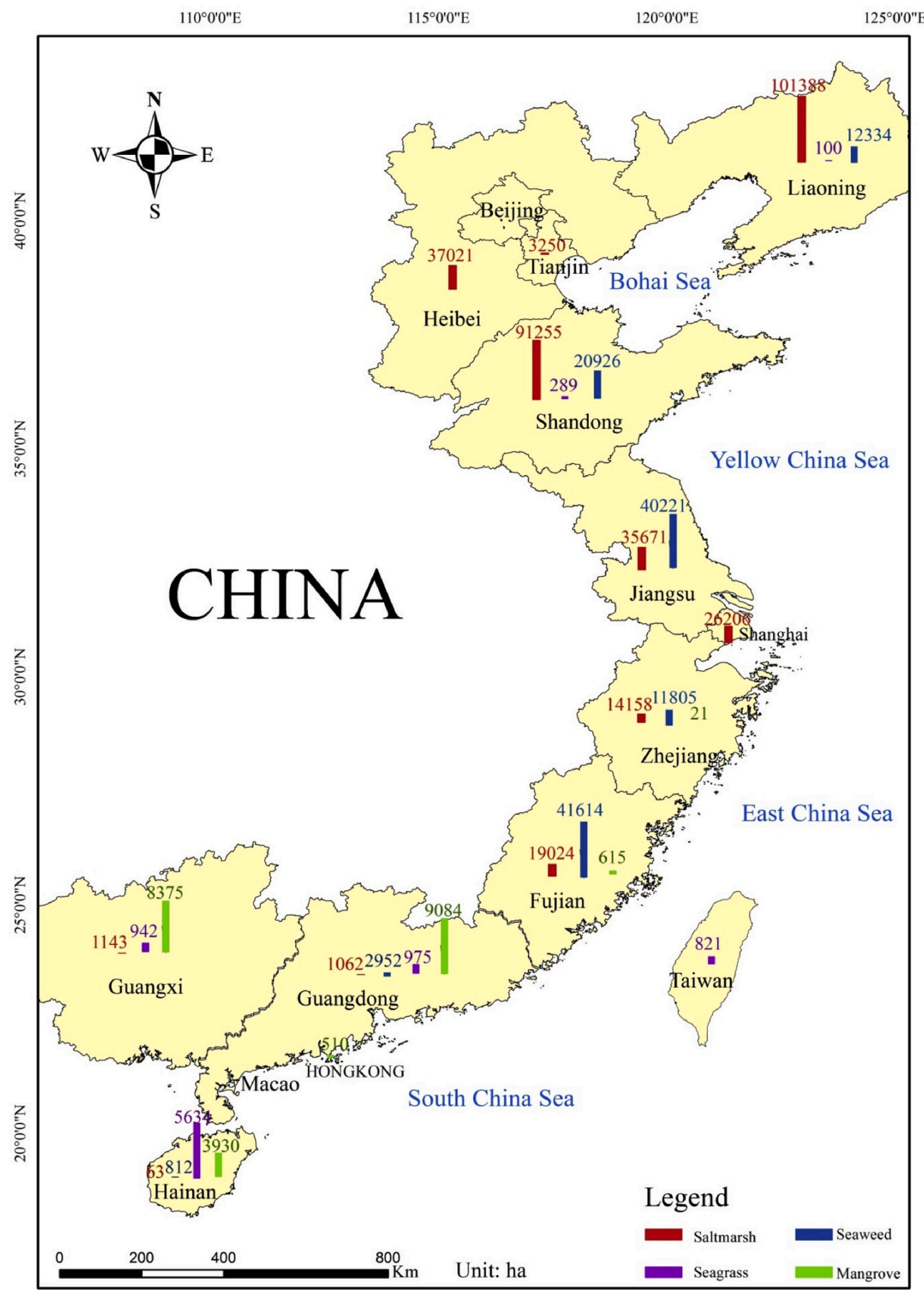

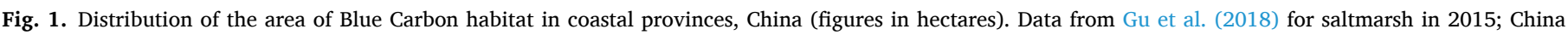

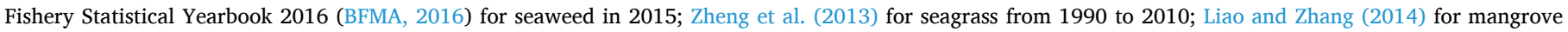
in 2001 . 

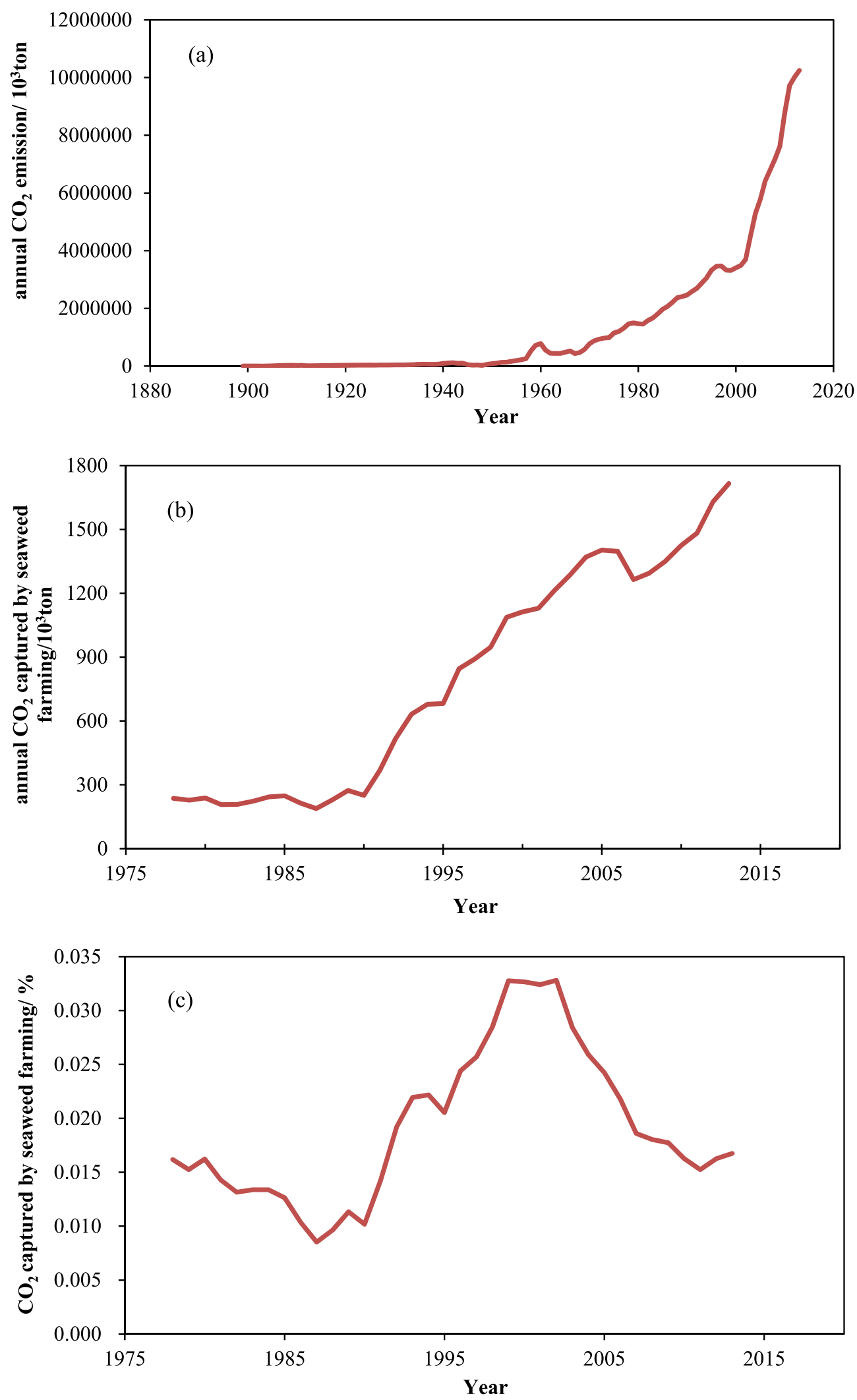

Fig. 2. (a) Annual Fossil Fuel $\mathrm{CO}_{2}$ emissions in China; (b) annual $\mathrm{CO}_{2}$ captured by seaweed farming in China; (c) the percentage of $\mathrm{CO}_{2}$ captured by seaweed farming in China in relation to Fossil Fuel $\mathrm{CO}_{2}$ emissions in China.

other aquatic plants in 2014 exceeded $13.1 \times 10^{6} \mathrm{t}$ wet weight (Ye et al., 2017). Over $98 \%$ of this harvest was from seaweed aquaculture, with $<2 \%$ being harvested from natural habitats (BFMA, 2015). Seaweeds have been widely used as sources of human and animal foods, fertilizers, pharmaceuticals, nutraceuticals, and biofuels and as biofilters to remove nutrients from coastal waters (Chopin et al., 2010; Fang et al., 2016; He et al., 2008; Neori, 2008; Troell et al., 1999; Xiao et al., 2017). Seaweed farming provides food with low $\mathrm{CO}_{2}$ footprints and serves as fertilizer 
with much reduced $\mathrm{CO}_{2}$ footprint relative to synthetic fertilizer production (Duarte et al., 2017; Xiao et al., 2017; Zheng et al., 2019). In 2015, the macroalgae farming area in China reached $1250 \mathrm{~km}^{2}$, and the total yield was 2 million tons in dry weight, which removed about 75 , 371 tons N and 9496 tons P from coastal waters (Xiao et al., 2017). Seaweed farming also saved an estimated nearly 1180 million tons freshwater for irrigation, and 171,958 tons N, 102,120 tons P and 133, 217 tons for chemical fertilizer in 2015 relative to land-based farming of a similarly large biomass, equivalent to about 1848 million Yuan RMB.

In other jurisdictions, macroalgae have been recognized as a viable option for $\mathrm{C}_{\text {org }}$ capture and storage (Chung et al., 2013; Sondak and Chung, 2015), this has, so far, not been the case in China. For example, due to seaweed cultivation as a significant $\mathrm{CO}_{2}$ sink, Korea has developed Coastal $\mathrm{CO}_{2}$ Removal Belts (CCRB), both natural and man-made plant communities in coastal regions of South Korea, to enhance $\mathrm{CO}_{2}$ removal by seaweed forests (Chung et al., 2013). When populated with the perennial brown alga Ecklonia, a pilot CCRB farm can draw down 10 $\mathrm{t}$ of $\mathrm{CO}_{2} \mathrm{ha}^{-1} \mathrm{yr}^{-1}$, some of which can be potentially sequestered (Duarte et al., 2017).

The high efficiency of nutrient removal by seaweed aquaculture has been projected to possibly result, at current growth rates, in nutrient depletion and limitation beyond a doubling of the current area (Xiao et al., 2017). Hence, provided current nutrient inputs, the maximum carrying capacity of Chinese coastal waters to support seaweed aquaculture will be reached in less than a decade (Xiao et al., 2017). Currently, seaweed aquaculture is deployed in coastal areas where the farms intercept nutrient inputs from land and, therefore, alleviate eutrophication, typically reducing nutrient concentrations by about half (Xiao et al., 2017). Added benefits of reducing eutrophication involve mitigation of hypoxia, which results from eutrophication, through both removing nutrients and directly injecting oxygen in coastal waters from seaweed photosynthesis. $\mathrm{CO}_{2}$ removal by seaweed farms also contributes to raise $\mathrm{pH}$ and alleviate ocean acidification (Chung et al., 2013; Duarte et al., 2017; Hendriks et al., 2014).

The total area of enclosed or semi-enclosed bays in China is about $27,760 \mathrm{~km}^{2}$, with about $5830 \mathrm{~km}^{2}$ (i.e. $20 \%$ ) currently in use for mariculture, of which seaweed aquaculture comprises $20 \%$ of the total area (BFMA, 2016). However, 90\% of the area in bays suitable for aquaculture is currently occupied, thus the scope for expansion is limited (Zhang et al., 2012a,b). Major expansion of seaweed aquaculture is possible either within the geographic footprint by polycultures with animal aquaculture, or the geographic expansion into exposed bays or offshore waters which are unsuitable under current practices. Below we propose a range of technological approaches that will increase the capacity of China to enhance seaweed production and, therefore, its potential role in climate change mitigation.
Further expansion of seaweed aquaculture to increase their potential for climate change mitigation would require seaweed aquaculture to expand offshore where nutrients can be supplied through technologies such as artificial upwelling (AU) powered by renewal energy and avoiding the risks of eutrophication and hypoxia in more nearshore coastal waters. AU transports cold, nutrient- and $\mathrm{CO}_{2}$-rich waters from below the thermocline to the euphotic zone where the nutrients and $\mathrm{CO}_{2}$ can be assimilated by the seaweeds with concomitant drawdown of $\mathrm{CO}_{2}$, and the production of plant biomass (Pan et al., 2015; Fan et al., 2016). The technique has been implemented in Aoshan Bay, Qingdao, China, a semi-closed bay (Table 2). The surface seawater is oligotrophic, and the sediments contain high nitrogen and phosphorus. Cultivation of Laminaria leads to nutrient limitation in spring due to the strong absorbing ability of seaweed, which can be overcome through nutrients delivered through artificial upwelling systems. This technique has also been applied in western Norwegian fjords to pump deep water to the surface to enhance nutrient concentrations and stimulate phytoplankton growth in an attempt to enhance fisheries production (Aure et al., 2007; Handå et al., 2013; McClimans et al., 2010).

In addition to nutrient availability, further expansion of seaweed aquaculture in China, and, thus, its emerging contribution to climate change mitigation is limited by current farming practices requiring sheltered conditions. High exposure to waves and strong tidal currents render many areas in coastal China seas unsuitable to support seaweed aquaculture (Burrows, 2012; Norderhaug et al., 2014; Tuya and Haroun, 2006). For example, during 2010 there were over 130 storm surges in Chinese coastal waters (Zhang et al., 2012a), which could have potentially damaged seaweed farms if they were in exposed locations. However, wave-absorbing devices can dissipate this energy, thereby allowing seaweed farming while also supplying mechanical energy to power AU that delivers nutrients to the surface layer or circulate the biomass to enhance exposure to light and, therefore, maximize yield. The wave energy technology has been successfully tested in Dongtou county, where Sargassum fusiforme farms are distributed (Table 2).

Offshore seaweed aquaculture in high energy environments can also be supported by implementing efficient anchoring systems together with buoyancy regulation systems to lower aquaculture rafts to depths protected from excessive wave action during storms, and raise the rafts subsequently. The anchoring system is essential in Sargassum fusiforme farming, which is always used to fix the rafts. This has been in practice in Dongtou county (Table 2). Prototypes of self-contained buoyancy regulation systems have been tested in Sargassum fusiforme farm. The buoyancy regulation systems are also being constructed to support offshore seaweed mariculture in New Zealand, in USA and in Germany (Goseberg et al., 2017). Hence, there is no technical barrier preventing buoyancy regulation systems to be used for macroalgae farming. The

Table 2

Summary of engineering solutions and innovative technologies to support the expansion of seaweed aquaculture in China.

\begin{tabular}{|c|c|c|c|c|}
\hline $\begin{array}{l}\text { Engineering solutions/ } \\
\text { innovative technologies }\end{array}$ & Challenges in expanding seaweed aquaculture & Functions & Increasing & $\begin{array}{l}\text { Implemented/Tested } \\
\text { locations in China }\end{array}$ \\
\hline $\begin{array}{l}\text { Artificial upwelling ( } \\
\text { Maruyama et al., 2004) }\end{array}$ & $\begin{array}{l}\text { Nutrient limitations due to strong absorbing ability } \\
\text { of seaweed. }\end{array}$ & $\begin{array}{l}\text { Bring high nutrient deep seawater to surface layer } \\
\text { where seaweed grows. }\end{array}$ & $\begin{array}{l}\text { Area, } \\
\text { Yield }\end{array}$ & $\begin{array}{l}\text { Laminaria cultivation in } \\
\text { Aoshan Bay, Qingdao City }\end{array}$ \\
\hline $\begin{array}{l}\text { Anchoring system ( } \\
\text { Roesijadi et al., 2008) }\end{array}$ & $\begin{array}{l}\text { Extension of seaweed farm from coastal to } \\
\text { offshore. }\end{array}$ & Offer platform for offshore seaweed aquaculture. & Area & $\begin{array}{l}\text { Sargassum fusiforme } \\
\text { cultivation in Dongtou } \\
\text { county }\end{array}$ \\
\hline $\begin{array}{l}\text { Artificial light } \\
\text { supplementary }\end{array}$ & $\begin{array}{l}\text { Light limitations in Chinese coast due to high water } \\
\text { turbidity, or long and continuous cloudy/rainy } \\
\text { period of weather. }\end{array}$ & $\begin{array}{l}\text { Promote seaweed growth and biosynthesize of } \\
\text { targeted bio-molecular, increasing the value of } \\
\text { seaweed products. }\end{array}$ & Yield & \\
\hline $\begin{array}{l}\text { Turn-over aquaculture } \\
\text { device }\end{array}$ & Lack of habitat for intertidal seaweed species. & $\begin{array}{l}\text { Providing artificial dry exposure condition for } \\
\text { seaweed }\end{array}$ & Area & $\begin{array}{l}\text { Porphyra cultivation in } \\
\text { Dayu Bay, Cang-nan County }\end{array}$ \\
\hline Wave energy technology & Too strong waves in seaweed aquaculture area. & Dissipate turbulence energy via wave absorbing. & Area & $\begin{array}{l}\text { Sargassum fusiforme } \\
\text { cultivation in Dongtou } \\
\text { county }\end{array}$ \\
\hline $\begin{array}{l}\text { Buoyancy regulation } \\
\text { system }\end{array}$ & Damage due to storms. & $\begin{array}{l}\text { Mechanically lowered and raise aquaculture rafts } \\
\text { to adjust the depth. }\end{array}$ & Area & $\begin{array}{l}\text { Sargassum fusiforme } \\
\text { cultivation in Dongtou } \\
\text { county }\end{array}$ \\
\hline
\end{tabular}


remaining issue is to lower the cost as to make the seaweed industry profitable. If successful, this development will allow large scale, sustainable seaweed farming, which, if properly managed, can contribute to climate change mitigation. However, these technologies would add costs to seaweed aquaculture, which may not be viable under the current market-based cost model. However, accounting for the greenhouse mitigation services of seaweed aquaculture through carbon credits, for which farmers are currently not compensated, may provide the additional income to afford the costs of deploying these engineering solutions. Hence, realizing the potential of seaweed aquaculture to contribute to climate change mitigation requires market and policy interventions and not only engineering solutions.

One good example for technological development already in place is the turn-over aquaculture device for Porphyra cultivation, developed in 2010 to provide artificial dry exposure conditions for Porphyra, which, in turn, enables greatly the extension of Porphyra farms from inter-tidal zone to near-coast, and to offshore (Table 2). This device has been implemented for years in Cangnan county, Zhejiang province, and in Fuding county, Fujian province, supporting the expansion of Porphyra cultivation, which provides high profit but is currently limited by the lack of habitat.

Most seaweed aquaculture yield in China is currently allocated to human food supply. This only marginally contributes to climate change mitigation through avoiding emissions associated with the production of similar food amounts in land-based agriculture which has a larger greenhouse gas footprint (Duarte et al., 2017). However, maximizing climate change mitigation through seaweed aquaculture requires that seaweed yield would be used for e.g. biofuel production (Duarte et al., 2017), long-lasting products and use of remaining waste for biochar production for soil amelioration (Bird et al., 2011). Yet, an industry for biofuel production from seaweed aquaculture, or long-lived seaweed based products, is currently lacking in China (Wei et al., 2013).

\section{Rationale and elements for a blue carbon program in China}

The government of China is committed to slow down or even reducing $\mathrm{CO}_{2}$ level as a commitment in the Paris Agreement, and to establish healthier ecosystems, for which it has invested tremendous efforts in marine ecosystem restoration. The 12th Five-Year Plan of National Marine Development (2013) and the "Mangrove in South and Tamarix chinensis in North" project in the 13th Five-Year Plan (2016-2020) illustrate this commitment at national level. The Fifth Plenary Session of the Eighteenth Central Committee of the Communist Party of China (26-29 October 2015) approved the "Blue Bay Project", setting goals for the restoration of coastal habitats (Ministry of Natural Resources, 2016). All these projects listed restoration of coastal vegetation as a national priority. Secretary General Xi reports to the Nineteenth Congress of the Communist Party of China (18-24 October 2017) included a chapter dedicated to the ocean, calling for (1) integrated land-ocean management; (2) enhanced efforts to address key marine environmental issues, protect shorelines and prevent coastal disasters; and (3) strengthen protection and restoration of coastal wetlands by joining global environmental initiatives. A national BC strategy would align with this aim while expanding the scope of existing national strategies (Table 3 ).

Many nations, both developed and developing ones, have defined national BC programs (e.g. Australia, France, Japan, Indonesia, Malaysia, Saudi Arabia), and China is now developing its national BC program. A BC strategy for China meets the criteria of being readily actionable, cost-effective and generating co-benefits, in terms of adding value towards existing national priorities (Table 3). We identify the following reasons supporting a national BC program in China:

1. China has lost about 77-87\% (Table 1) of the natural BC habitat, with great impacts on biodiversity, ecosystem health and environmental quality.
Table 3

China's national policies aligned with Blue Carbon strategies.

\begin{tabular}{|c|c|c|}
\hline Projects & Goals & Status quo \\
\hline $\begin{array}{l}\text { The 12th Five-Year } \\
\text { Plan of National } \\
\text { Marine } \\
\text { Development } \\
\text { "Mangrove in South } \\
\text { and Tamarix } \\
\text { chinensis in } \\
\text { North"Project }\end{array}$ & $\begin{array}{l}200 \mathrm{~km}^{2} \text { new wetland (100 } \\
\mathrm{km}^{2} \text { mangroves, and } 100 \\
\mathrm{~km}^{2} \text { Phragmites australis } \\
\text { wetland). } \\
2500 \text { ha mangrove in south } \\
\text { China, } 4000 \text { ha Phragmites } \\
\text { australis, } 1500 \text { ha of Suaeda } \\
\text { salsa, and } 500 \text { ha of Tamarix } \\
\text { chinensis in north China }\end{array}$ & $\begin{array}{l}\text { The area of mangrove in } \\
\text { China decrease from about } \\
420 \mathrm{~km}^{2} \text { in } 1950 \text { s to } 345 \\
\mathrm{~km}^{2} \text { in } 2013 \text {. }\end{array}$ \\
\hline $\begin{array}{l}\text { Marine Ecological } \\
\text { Redline }\end{array}$ & $\begin{array}{l}\text { Natural coastline should be } \\
\text { no less than } 35 \% \text { and coastal } \\
\text { waters of good water quality } \\
\text { (case one or case two) } \\
\text { should reach the proportion } \\
\text { of about } 70 \% \text { by } 2020 \text {. }\end{array}$ & $\begin{array}{l}\text { The China natural } \\
\text { coastline keeps declining } \\
\text { since } 1940 \text { s, and there is } \\
\text { less than } 30 \% \text { left in } 2014 \text {; } \\
\text { the case one and case two } \\
\text { waters in coastal area are } \\
33.6 \% \text { and } 36.9 \% \\
\text { respectively. }\end{array}$ \\
\hline $\begin{array}{c}\text { "Blue Bay" renovation } \\
\text { project }\end{array}$ & $\begin{array}{l}\text { Enlarge the area of coastal } \\
\text { wetland and meet } \\
\text { environmental standard in } \\
\text { bay areas. }\end{array}$ & $\begin{array}{l}\text { Between } 2000 \text { and } 2010 \text {, } \\
\text { the area of coastal wetland } \\
\text { decreased by } 3288 \mathrm{~km}^{2} \text {, } \\
\text { and the artificial wetland } \\
\text { increased by } 2592 \mathrm{~km}^{2} \text {. }\end{array}$ \\
\hline
\end{tabular}

2. China is already investing heavily in the restoration and conservation of $\mathrm{BC}$ habitats, such as mangrove and saltmarsh habitats (Table 3), but is only recently considering computing the carbon mitigation value associated with these projects in its Nationally Determined Contributions. Accounting for this on-going carbon sequestration will help meet the commitments of China under the Paris Agreement.

3. China has developed a massive seaweed aquaculture industry, which has created thus far $1250 \mathrm{Km}^{2}$ of seaweed habitat, growing at $8 \%$ per year, with important - but yet unrealized - potential for climate change mitigation and adaptation.

4. The development of a BC program around seaweed aquaculture will catalyze the further growth of this blooming industry, which is delivering major benefits to Chinese economy and helping alleviate coastal eutrophication - a major national problem.

5. A national $\mathrm{BC}$ program will provide a cost-effective contribution to meeting China's objectives under the Paris Agreement.

6. A BC program may develop pioneer technology for carbon capture that can be exported elsewhere, generating additional value and opportunities for economic development.

7. Restoration and creation of coastal habitats will contribute to protect the vulnerable low-lying shorelines of China from sea level rise and storm surges, thereby avoiding losses of hundreds of lives and billions of RMB every year.

8. Restoration and creation of coastal habitats will contribute to generate nursery habitats for fish and other marine organisms of commercial value that will contribute to enhance the stocks and recover them from overexploitation.

Further, we propose that a BC program in China should consider the following elements:

1. Capacity building: Develop capacity within China's scientific community, both graduate students and early career researchers (e.g. junior faculty) and coastal management and policy agencies, to provide the knowledge, technology and policy frameworks supporting a national BC program.

2. Evaluation of $\mathrm{BC}$ resources: Evaluate the current extent, losses and gains of BC habitats, and the green-house gas emissions associated with these changes.

3. Demonstration of the value of seaweed aquaculture as a $\mathrm{BC}$ resource in China: Examine the $\mathrm{CO}_{2}$ sequestration capacity of seaweed farms and the management and marketing options supporting a $\mathrm{BC}$ role. 
4. Assessment of the contribution of restoration and conservation of $\mathrm{BC}$ habitats in China to national climate change policies.

5. Development of novel BC technologies: e.g. technologies to increase carbon capture by seaweed farms, and the potential use of marine plant litter to minimize Green House Gas emissions from agriculture.

6. Policy and Management: Development of policies and management tools to govern $\mathrm{BC}$ resources as to deliver the full potential of environmental benefits, involving fishermen and seaweed farmers in meeting the strategic objectives.

7. Establishment and improvement of nation-wide Carbon trade market: Based on the experience of existed carbon trade pilots, gradually and steadily establish nation-wide carbon trade market while including seaweed aquaculture into the carbon trade.

China's extensive coastline, loss of coastal habitats and vulnerability to climate change provide the opportunity, and necessity, to develop a strong BC program. While its contribution to address the nation's commitments under the Paris Agreement will be modest, the emerging BC program in China is poised to catalyze the restoration and conservation of coastal habitats, generating major benefits for all. Accordingly, the State Ocean Administration of China has taken the lead in BC actions in China through a series of actions, including compilation of a report on BC in China, released at the 2017 International Blue Carbon Forum held in Xiamen, China, November 4-5, 2017, the inclusion of BC in China's first biennial update report on climate change, preparation of a number of demonstration projects of technical standards for BC monitoring, and international cooperation in $\mathrm{BC}$ research with Thailand, Malaysia and Indonesia. With its extensive coastline and commitment, China is poised to play a key role in the implementation of BC strategies for climate change mitigation and adaptation.

\section{Declaration of competing interest}

Compliance with ethics guidelines: All authors (Jiaping $\mathrm{Wu}$, Haibo Zhang, Yiwen Pan, Dorte Krause-Jensen, Zhiguo He, Wei Fan, Xi Xiao, Ikkyo Chung, Nuria Marbà, Oscar Serrano, Richard B. Rivkin, Yuhan Zheng, Jiali Gu, Xiujuan Zhang, Zhaohui Zhang, Peng Zhao, Wanfei Qiu, Guangcheng Chen, Carlos M. Duarte) declare that they have no conflict of interest or financial conflicts to disclose.

\section{Acknowledgements}

This research was funded by the Program of International Science \& Technology Cooperation, the Ministry of Science and Technology of China (grant \# 2015DFA01410,Bioremediation of polluted coastal water and carbon sequestration) and Zhejiang Provincial Department of Science and Technology (2016C04004). We were grateful to Profs. Nianzhi Jiao and Rui Zhang from Xiamen University, and Prof. Yongming Luo from Yantai Institute of Coastal Zone Research, Chinese Academy of Sciences, China for their encouragement on this work. We were also very grateful to Drs. Zhanhai Zhang, Yan Liu, Shengzhi Sun and Haiwen Zhang from the State Oceanic Administration, China and Mr. Jie Xu from the Ministry of Science and Technology, China for their support. The views from this work are purely from authors, and are not implied or approved in any sense by any affiliation of authors.

\section{References}

Aure, J., Strand, Ø., Erga, S.R., Strohmeier, T., 2007. Primary production enhancement by artificial upwelling in a western Norwegian fjord. Res. Vet. Sci. 34 (1), 77-81. Barrón, C., Duarte, C.M., 2016. Dissolved organic carbon pools and export from the coastal ocean. Global Biogeochem. Cycles 29 (10), 1725-1738.

Barron, C., Apostolaki, E.T., Duarte, C.M., 2014. Dissolved organic carbon fluxes by seagrass meadows and macroalgal beds. Front. Mar. Sci. 1, 42.

Bureau of Fisheries the Ministry of Agriculture (BFMA), 2015. China Fishery Statistical Yearbook 2014. China Agriculture Press.

Bureau of Fisheries the Ministry of Agriculture (BFMA), 2016. China Fishery Statistical Yearbook 2015. China Agriculture Press.
Bird, M.I., Wurster, C.M., de Paula Silva, P.H., Bass, A.M., de Nys, R., 2011. Algal biochar-production and properties. Bioresour. Technol. 102 (2), 1886-1891.

Brennan, J., 2011. FAO 2003 - state of the world's forests. Food Agri. Organ. United Nat. FAO 54 (2), 165-166.

Burrows, M.T., 2012. Influences of wave fetch, tidal flow and ocean colour on subtidal rocky communities. Mar. Ecol. Prog. 445, 193-207.

Chen, L.Z., Wang, W.Q., Zhang, Y.H., Lin, G.H., 2009. Recent progresses in mangrove conservation, restoration and research in China. J. Plant Ecol. 2 (2), 45-54.

Chopin, T., Troell, M., Reid, G.K., Knowler, D., Robinson, S.M.C., Neori, A., Buschmann, A.H., Pang, S.J., 2010. Integrated multi-trophic aquaculture. Part I. Responsible practice provides diversified products, biomitigation. Global Aqua. Adv. 13 (5), 38-39.

Chung, I.K., Oak, J.H., Jin, A.L., Shin, J.A., Kim, J.G., Park, K.S., 2013. Installing kelp forests/seaweed beds for mitigation and adaptation against global warming: Korean Project Overview. ICES J. Mar. Sci. 70 (5), 1038-1044.

Colombini, I., Chelazzi, L., 2003. Influence of marine allochthonous input on sandy beach communities. Oceanogr. Mar. Biol. 41, 115-159.

Duan, X.N., Fei, X.K., 2008. Carbon sequestration and its potential by wetland ecosystems in China. Acta Ecol. Sin. 28 (2), 463-469.

Duarte, C.M., 1992. Nutrient concentration of aquatic plants: patterns across species. Limnol. Oceanogr. 37 (4), 882-889.

Duarte, C.M., Cebrián, J., 1996. The fate of marine autotrophic production. Limnol. Oceanogr. 41 (8), 1758-1766.

Duarte, C.M., Losada, I.J., Hendriks, I.E., Mazarrasa, I., Marbà, N., 2013. The role of coastal plant communities for climate change mitigation and adaptation. Nat. Clim. Change 3 (11), 961-968.

Duarte, C.M., Wu, J.P., Xiao, X., Bruhn, A., Krause-Jensen, D., 2017. Can seaweed farming play a role in climate change mitigation and adaptation? Front. Mar. Sci. 4.

Duggins, D.O., Gómez-Buckley, M.C., Buckley, R.M., Lowe, A.T., Galloway, A.W.E., Dethier, M.N., 2016. Islands in the stream: kelp detritus as faunal magnets. Mar. Biol. $163(1), 1-10$.

Fan, W., Pan, Y., Zhang, D., Xu, C., Qiang, Y., Chen, Y., 2016. Experimental study on the performance of a wave pump for artificial upwelling. Ocean Eng. 113, 191-200.

Fang, J., Zhang, J., Xiao, T., Huang, D., Liu, S., 2016. Integrated multi-trophic aquaculture (IMTA) in sanggou bay, China. Agri. Environ. Interac. 8, 201-205.

FAO, 2010. The state of world fisheries and aquaculture 2016 (SOFIA): contributing to food security and nutrition for all. State World Fish. Aqua. 4 (1), 40-41.

Filbee-Dexter, K., Scheibling, R.E., 2012. Hurricane-mediated defoliation of kelp beds and pulsed delivery of kelp detritus to offshore sedimentary habitats. Mar. Ecol. Prog. 455, 51-64.

Froehlich, H.E., Afflerbach, J.C., Frazier, M., Halpern, B.S., 2019. Blue growth potential to mitigate climate change through seaweed offsetting. Curr. Biol. 29 (18), 3087-3093.

Fu, X.M., Wang, Y.N., Shao, C.L., Wang, C.Y., Li, G.Q., Liu, G.X., Sun, S.C., Zeng, X.O, Ye, Z.J., Guan, S.H., 2009. Investigation on the Status of Mangrove Resources and Medicinal Research in China II. Resources Status, Protection and Management, vol. 39. Periodical of Ocean University of China, pp. 705-711, 4.

Gallo, N.D., Victor, D.G., Levin, L.A., 2017. Ocean communities under the Paris agreement. Nat. Clim. Change 7, 833-838.

Gattuso, J.P., Magnan, A.K., Bopp, L., Cheung, W.W.L., Duarte, C.M., Hinkel, J., Mcleod, E., Micheli, F., Oschlies, A., Williamson, P., Billé, R., Chalastani, V.I. Gates, R.D., Irisson, J.O., Middelburg, J.J., Pörtner, H.O., Rau, G.H., 2018. Ocean solutions to address climate change and its effects on marine ecosystems. Front. Mar. Sci. 5, 337.

Goseberg, Nils, Chambers, Michael D., Kevin, Heasman, Fredriksson, David, Fredheim, Arne, Schlurmann, Torsten, 2017. Technological Approaches to Longlineand Cage-Based Aquaculture in Open Ocean Environments. Springer International Publishing.

Gu, J., Luo, M., Zhang, X., Christakos, G., Augsti, S., Duarte, C.M., Wu, J., 2018. Losses of salt marsh in China: trends, threats and management. Estuarine. Coast. Shelf Sci. 214, 98-109.

Guan, D.M., 2012. Chinese Coastal Wetlands. China Ocean Press (in Chinese).

Guan, Y., Zheng, F., Zhang, P., Qin, C., 2015. Spatial and temporal changes of meteorological disasters in China during 1950-2013. Nat. Hazards 75 (3), 2607-2623.

Hamilton, S.E., Casey, D., 2016. Creation of a high spatio-temporal resolution global database of continuous mangrove forest cover for the 21st century (CGMFC-21). Global Ecol. Biogeogr. 25 (6), 729-738.

Handå, A., Forbord, S., Wang, X., Broch, O.J., Dahle, S.W., Størseth, T.R., Reitan, K.I., Olsen, Y., Skjermo, J., 2013. Seasonal-and depth-dependent growth of cultivated kelp (Saccharina latissima) in close proximity to salmon (Salmo salar) aquaculture in Norway. Aquaculture 414, 191-201.

He, P., Xu, S., Zhang, H., Wen, S., Dai, Y., Lin, S., Yarish, C., 2008. Bioremediation efficiency in the removal of dissolved inorganic nutrients by the red seaweed, Porphyra yezoensis, cultivated in the open sea. Water Res. 42 (4-5), 1281.

Hendriks, I.E., Olsen, Y.S., Ramajo, L., Basso, L., Steckbauer, A., Moore, T.S., Howard, J., Duarte, C.M., 2014. Photosynthetic activity buffers ocean acidification in seagrass meadows. Biogeosciences 11 (7), 333-346.

Herr, D., Landis, E., 2016. Coastal Blue Carbon Ecosystems. Opportunities for Nationally Determined Contributions. Policy Brief. IUCN, Gland, Switzerland (Washington, DC, USA: TNC).

Hill, R., Bellgrove, A., Macreadie, P.I., Petrou, K., Beardall, J., Steven, A., Ralph, P.J., 2015. Can macroalgae contribute to blue carbon? An Australian perspective. Limnol. Oceanogr. 60 (5), 1689-1706.

Jia, M., Wang, Z., Zhang, Y., Ren, C., Song, K., 2015. Landsat-based estimation of mangrove forest loss and restoration in Guangxi province, China, influenced by 
human and natural factors. IEEE J. Select. Topic. Appl. Earth Observ. Rem. Sens. 8 (1), 311-323.

Jiao, N., Herndl, G.J., Hansell, D.A., Benner, R., Kattner, G., Wilhelm, S.W., Kirchman, D. L., Weinbauer, M.G., Luo, T., Chen, F., Azam, F., 2010. Microbial production of recalcitrant dissolved organic matter: long-term carbon storage in the global ocean. Nat. Rev. Microbiol. 8 (8), 593-599.

Kauffman, J.B., Heider, C., Norfolk, J., Payton, F., 2014. Carbon stocks of intact mangroves and carbon emissions arising from their conversion in the Dominican Republic. Ecol. Appl. 24 (3), 518-527.

Kennedy, H., Beggins, J., Duarte, C.M., Fourqurean, J.W., Holmer, M., Marbà, N., Middelburg, J.J., 2010. Seagrass sediments as a global carbon sink: isotopic constraints. Global Biogeochem. Cycles 24 (4).

Kirwan, M.L., Megonigal, J.P., 2013. Tidal wetland stability in the face of human impacts and sea-level rise. Nature 504 (7478), 53-60.

Kong, W., Liang, R., Wang, S.J., Liu, Y.F., 2016. Spatial and temporal evolution of the ecological environment and economy coordinated development in Hebei Province, China. Chin. J. Appl. Ecol. 27 (9), 2941-2949. https://doi.org/10.13287/j.10019332.201609.030 (in Chinese).

Krause-Jensen, D., Duarte, C.M., 2016. Substantial role of macroalgae in marine carbon sequestration. Nat. Geosci. 9 (10).

Krause-Jensen, D., Lavery, P., Serrano, O., Marbà, N., Masque, P., Duarte, C.M., 2018. Sequestration of macroalgal carbon: the elephant in the Blue Carbon room. Biol. Lett. 14, 20180236.

Krumhansl, K.A., Okamoto, D.K., Rassweiler, A., Novak, M., Bolton, J.J., Cavanaugh, K. C., Connell, S.D., Johnson, C.R., Konar, B., Ling, S.D., 2016. Global patterns of kelp forest change over the past half-century. Proc. Natl. Acad. Sci. U. S. A. 113 (48), 13785-13790.

Krumhansl, K.A., Scheibling, R., 2012. Production and fate of kelp detritus. Mar. Ecol. Prog. Ser. 467, 281-302.

Liao, B.W., Zhang, Q.M., 2014. Area, distribution and species composition of mangroves in China. Wet. Sci. 12 (4), 435-440.

Lovelock, C.E., Duarte, C.M., 2019. Dimensions of blue carbon and emerging perspectives. Biol. Lett. 15, 20180781.

Lu, C., Wang, Z., Li, L., Wu, P., Mao, D., Jia, M., Dong, Z., 2016. Assessing the conservation effectiveness of wetland protected areas in Northeast China. Wetl. Ecol. Manag. 24 (4), 1-18.

Macreadie, P.I., Anton, A., Raven, J.A., Beaumont, N., Connolly, R.M., Friess, D.A., Kelleway, J.J., Kennedy, H., Kuwae, T.,

, Lavery, P.S., Lovelock, C.E., Smale, D.A., Apostolaki, E.T., Atwood, T.B., Baldock, J., Bianchi, T.S., Chmura, G.L., Eyre, B.D., Fourqurean, J.W., HallSpencer, J.M., Huxham, M., Hendriks, I.E., Krause-Jensen, D., Laffoley, D., Luisetti, T., Marba, N., Masque, P., McGlathery, K.J., Megonigal, J.P., Murdiyarso, D., Russell, B.D., Santos, R., Serrano, O., Silliman, B.R., Watanabe, K. Duarte, C.M., 2019. The future of blue carbon science. Nat. Commun. 10, 3998.

Maruyama, S., Tsubaki, K., Taira, K., Sakai, S., 2004. Artificial upwelling of deep seawater using the perpetual salt fountain for cultivation of ocean desert. J. Oceanogr. 60 (3), 563-568.

McClimans, T.A., Handå, A., Fredheim, A., Lien, E., Reitan, K.I., 2010. Controlled artificial upwelling in a fjord to stimulate non-toxic algae. Aquacult. Eng. 42 (3), $140-147$.

Mcleod, E., Chmura, G.L., Bouillon, S., Salm, R., Björk, M., Duarte, C.M., Lovelock, C.E., Schlesinger, W.H., Silliman, B.R., 2011. A blueprint for blue carbon: toward an improved understanding of the role of vegetated coastal habitats in sequestering CO2. Front. Ecol. Environ. 9 (10), 552-560.

Miller, R., Reed, D., Brzezinski, M., 2009. Community structure and productivity of subtidal turf and foliose algal assemblages. Mar. Ecol. Prog. 388 (1), 1-11.

Ministry of Natural Resources, 2016. The overall plan (for oceanic matter of China). http://www.mnr.gov.cn/zt/hy/2016qghygzhy/2016_qghygzhy ztsl/201601/t20 160125_2105681.html (in Chinese).

Miyajima, T., Hori, M., Hamaguchi, M., Shimabukuro, H., Adachi, H., Yamano, H., Nakaoka, M., 2015. Geographic variability in organic carbon stock and accumulation rate in sediments of East and Southeast Asian seagrass meadows. Global Biogeochem. Cycles 29 (4), 397-415.

Mork, M., 1996. Wave Attenuation Due to Bottom Vegetation.

Nellemann, C., Corcoran, E., Duarte, C.D., Valdés, L., Young, C., De, Fonseca, L, Grimsditch, G., 2009. Blue Carbon: the Role of Healthy Oceans in Binding Carbon, Rapid Response Assessment. United Nations Environment Programme. GRID Arendal 80

Neori, A., 2008. Essential role of seaweed cultivation in integrated multi-trophic aquaculture farms for global expansion of mariculture: an analysis. J. Appl. Phycol. 20 (5), 567-570.

Nicholls, R.J., Hanson, S., Herweijer, C., Patmore, N., Hallegatte, S., Corfee-Morlot, J., Chateau, J., Muir-Wood, R., 2007. Ranking of the world's cities most exposed to coastal flooding today and in the future'. In: OECD Environment Working Paper.

Niu, Z., Zhang, H., Wang, X., Yao, W., Zhou, D., Zhao, K., Zhao, H., Li, N., Huang, H., Li, C., 2012. Mapping wetland changes in China between 1978 and 2008. Chin. Sci. Bull. 57, 2813-2823.

Norderhaug, Kjell M., Hartvig, C.C., Eli, R., Hege, G., Trine, B., 2014. Importance of Wave and Current Exposure to Fauna Communities in Laminaria Hyperborea Kelp Forest.
Ortega, A., Geraldi, N.R., Alam, I., Kamau, A.A., Acinas, S.G., Logares, R., Gasol, J.M., Massana, R., Krause-Jensen, D., Duarte, C.M., 2019. Important contribution of macroalgae to oceanic carbon sequestration. Nat. Geosci. 12, 748-754.

Pan, Y., Fan, W., Huang, T., Wang, S., Chen, C.A., 2015. Evaluation of the sinks and sources of atmospheric CO2 by artificial upwelling. Sci. Total Environ. 511, 692.

Peng, Y.S., Chen, G.Z., Li, S.Y., Liu, Y., Pernetta, J.C., 2013. Use of degraded coastal wetland in an integrated mangrove-aquaculture system: a case study from the South China Sea. Ocean Coast Manag. 85 (4), 209-213.

Queirós, A.M., Stephens, N., Widdicombe, S., Tait, K., McCoy, S.J., Ingels, J., Rühl, S., Airs, R., Beesley, A., Carnovale, G., Cazenave, P., 2019. Connected macroalgalsediment systems: blue carbon and food webs in the deep coastal ocean. Ecol. Monogr., e01366

Ren, G.Z., Zhang, Q.X., Wang, J.C., Wang, D.J., 1991. Transplant eelgrasses in shrimp ponds to increase products of penaeus chinensis o'sbeck. Mar. Sci. 1, 52-57.

Roesijadi, G., Copping, A.E., Huesemann, M.H., Forster, J., Benemann, J.R., 2008. Techno-economic Feasibility Analysis of Offshore Seaweed Farming for Bioenergy and Biobased Products. Independent research and development report IR\# PNWD-3931, Battelle Pacific Northwest Division 115.

Shu, L., Chen, P., Jia, X., Li, C., Li, X., 2011. Seagrass transplantation in artificial fishing reefs and limited factor. J. Fish. Sci. China 18 (4), 893-898.

Sidik, F., Lovelock, C.E., 2013. $\mathrm{CO}_{2}$ efflux from shrimp ponds in Indonesia. PloS One 8 (6), e66329.

Sondak, C.F.A., Chung, I.K., 2015. Potential blue carbon from coastal ecosystems in the Republic of Korea. Ocean Sci. J. 50 (1), 1-8.

Sun, C., Liu, Y.X., Li, M.C., Zhao, S.S., Zhou, M.X., 2015. Spatiotemporal evolution of SaltMarsh and influential analysis of reclamation of Jiangsu middle coast in recent 25 years. J. Nat. Resour. 30 (9), 1486-1498.

Troell, M., Rönnbäck, P., Halling, C., Kautsky, N., Buschmann, A., 1999. Ecological engineering in aquaculture: use of seaweeds for removing nutrients from intensive mariculture. J. Appl. Phycol. 11 (1), 89-97.

Tuya, F., Haroun, R., 2006. Spatial patterns and response to wave exposure of shallow water algal assemblages across the Canarian Archipelago. Multi Scaled App. 311 (8), $15-28$.

van Katwijk, M.M., Thorhaug, A., Marbà, N., Orth, R.J., Duarte, C.M., Kendrick, G.A., Althuizen, I.H.J., Balestri, E., Bernard, G., Cambridge, M.L., 2016. Global analysis of seagrass restoration: the importance of large-scale planting. J. Appl. Ecol. 53 (2), $567-578$.

van Kleef, G.A., Cheshin, A., Fischer, A.H., Schneider, I.K., 2016. Editorial: the social nature of emotions. Front. Psychol. 7.

Wei, N., Quarterman, J., Jin, Y., 2013. Marine macroalgae: an untapped resource for producing fuels and chemicals. Trends Biotechnol. 31 (2), 70.

Wilkie, M.L., Fortuna, S., 2003. Status and trends in mangrove area extent worldwide. In: Forest Resources Assessment Working Paper 63, Forest Resources Division. FAO. Forest Resources Assessment Programme Working Paper.

Xiao, X., Agusti, S., Lin, F., Li, K., Pan, Y., Yu, Y., Zheng, Y., Wu, J., Duarte, C.M., 2017. Nutrient removal from Chinese coastal waters by large-scale seaweed aquaculture. Sci. Rep. 7, 46613.

Xu, H., Liu, Z., Wang, L., Wan, H., Jing, C., Jiang, J., Wu, J., Qi, J., 2018. Trade-offs and spatial dependency of rice production and environmental consequences at community level in Southeastern China. Environ. Res. Lett. 13 (2), 024021.

Ye, Y., Barange, M., Beveridge, M., Garibaldi, L., Gutierrez, N., Anganuzzi, A Taconet, M., 2017. FAO's statistical databases and the sustainability of fisheries and aquaculture: comments on Pauly and Zeller 2017. Mar. Pol. 81.

Yu, J., Wang, Y., Li, Y., Dong, H., 2012. Soil organic carbon storage changes in coastal wetlands of the modern Yellow River Delta from 2000 to 2009. Biogeosci. Discuss. 9 (2), 2325-2331.

Zeng, C.K., 1962. Economic Algae Blooms in China. Science Press.

Zhang, F., Zhan, W.H., Yao, Y.T., Sun, J., Zhan, M.Z., 2012a. Current situation and causes of coastal erosion in eastern Moyang River Estuary. J. Trop. Oceanogr. 31 (2), 41-46.

Zhang, J., Fang, J., Wang, W., Du, M., Gao, Y., Zhang, M., 2012b. Growth and loss of mariculture kelp Saccharina japonica in Sungo Bay, China. J. Appl. Phycol. 24 (5), 1209-1216.

Zhang, L.Q., Yuan, L., Huang, H.M., 2015. Coastal Wetlands in the Changjiang Estuary. Springer International Publishing.

Zhang, S.J., 1996. The species and distribution of seaweeds in the coast of China seas. Chin. Biodivers. 4 (3), 139-144 (in Chinese).

Zhang, X.L., Li, P.Y., Xu, X.Y., 2005. Present conditions and prospects of study on coastal wetlands in China. Adv. Mar. Sci. 23 (1), 87-95.

Zhang, Y.M., Shi, D.Z., 2007. The condition and trends of the world's ecosystem services. Adv. Earth Sci. 22 (5), 515-520.

Zheng, F.Y., Qiu, G.L., Fan, H.Q., Zhang, W., 2013. Diversity, distribution and conservation of Chinese seagrass species. Biodivers. Sci. 21 (5), 517-526 (in Chinese).

Zheng, Y., Jin, R., Zhang, X., Wang, Q., Wu, J., 2019. The considerable environmental benefits of seaweed aquaculture in China. Stoch. Environ. Res. Risk Assess. 33 (4), 1203-1221.

Zuo, P., Li, Y., Liu, C., Zhao, S., Guan, D., 2013. Coastal wetlands of China: changes from the 1970 s to 2007 based on a New wetland classification system. Estuar. Coast 36 (2), 390-400. https://doi.org/10.1007/s12237-012-9575-y.

Zuo, P., Zhao, S., Liu, C., Wang, C., Liang, Y., 2012. Distribution of Spartina spp. along China's coast. Ecol. Eng. 40, 160-166. 